\title{
LONG-TERM WEATHER DATA MEASUREMENTS FROM A DANISH CLIMATE STATION AND THE WEATHER'S INFLUENCE ON THE THERMAL PERFORMANCE OF SOLAR COLLECTORS
}

Lukáš SKALÍl ${ }^{1 *}$

\section{Abstract}

A weather data evaluation from a climate station in Lyngby, Denmark, was carried out. Twenty years of measurements show that the increase in global radiation was almost $3.5 \mathrm{kWh} /$ $\mathrm{m} 2$ per year, corresponding to a growth of the yearly global radiation of $7 \%$ for the last 20 years. The global radiation variation between the least sunny year to the sunniest year was $20 \%$. The increase in diffuse radiation was $1.9 \mathrm{kWh} / \mathrm{m} 2$ per year, corresponding to 20 years' growth of up to $7 \%$. The annual diffuse radiation of nearly $19 \%$ varied from the least cloudy year to the cloudiest year. A small increase was measured for the ambient air temperature. The measurements showed a yearly increase of $0.04 \mathrm{~K}$ per year. The average yearly ambient air temperature variation from the coldest to the warmest year was $3.1 \mathrm{~K}$. According to the seasonal growth of the parameters measured, the ambient air temperature and diffuse radiation increased the most in the summer period, while the global radiation significantly increased in the spring months. The calculations of the solar collector's thermal performance in Lyngby showed that the energy output was mostly dependent on beam radiation. The ambient air temperature did not have a high influence on the thermal performance of the solar collectors compared to the influence of the total solar radiation.
Address

1 Department of Building Services, Faculty of Civil Engineering, Slovak University of Technology in Bratislava, Radlinského 11, 81005 Bratislava, Slovakia

* Corresponding author: lukas.skalik@stuba.sk

\section{Key words}

- Climate change,

- solar radiation variations,

- solar collectors,

- solar collector efficiency,

- ambient air temperature,

- energy utilization.

\section{INTRODUCTION}

In connection with the planning and optimization of energy-efficient buildings and solar energy systems, it is important to know the climate data of the area where the buildings/systems are located. This study is based on measured weather data from a climate station located at the Technical University of Denmark, Kgs. Lyngby, and it shows how the thermal performance of solar collectors is influenced by weather variations.

The climate is one of the key factors influencing the energy yield of a solar heating system. This interaction takes place on several levels (Weiss, 2003):
- Solar collector:

- The collector's efficiency is influenced by beam radiation, diffuse radiation and ambient air temperature.

- Heat demands of the building:

- Heat losses to the ambient are driven by the difference in temperature between the house and the ambient (air and ground).

- Solar radiation through the windows can be seen as an internal heat gain in the period of the year when space heating is needed (the heating season). 
- Domestic hot water demand:

- The cold water temperature from the mains varies over the year. This variation is mainly dependent on the average monthly ambient temperatures.

Throughout the world, design reference years have been developed for different locations. The weather data in the design reference years are derived from measured weather data for periods of 15-20 years, and what is common for all the locations is that the weather varies from one year to another. Although the results in this study are based on the Danish weather data measured, the results are not specific for Danish conditions, but show how the thermal performance of solar heating systems and solar collectors is generally influenced by weather variations.

The thermal performance of solar heating systems can both directly and indirectly be influenced by the weather. The efficiency and energy production of a solar collector is directly influenced by the weather, especially by the solar irradiance on the collector and the ambient air temperature. The space heating demands of buildings are influenced by the weather, especially by the ambient air temperature and the solar radiation on the windows. The thermal performance of solar heating systems is therefore both directly and indirectly influenced by the weather.

\section{MATERIALS/METHODS}

\subsection{Global radiation measurements}

The total amount of solar radiation received by a horizontal (ground) surface is called ,global radiation”. Global radiation is thus the sum of the direct radiation from the sun and the diffuse radiation from the rest of the sky, i.e., the solar radiation scattered by atmospheric molecules and particles or reflected by clouds. What is measured and read by the instruments is called global irradiance, more specifically, global horizontal irradiance (GHI) or global tilted irradiance (GTI), which is the incident radiation power per unit area, and reported in units of $\mathrm{W} / \mathrm{m}^{2}$. Through integration over time it is the total radiation energy per unit area for a specified period, such as hours, days, months or years. This quantity is designated as global irradiation, and the monthly and annual values indicated are given in $\mathrm{kWh} / \mathrm{m}^{2}$ or $\mathrm{MJ} / \mathrm{m}^{2}$ $\left(1 \mathrm{kWh} / \mathrm{m}^{2}=3.6 \mathrm{MJ} / \mathrm{m}^{2}\right)$. Often, however, the term global radiation as a general expression is used for both global irradiance (GHI and GTI) and global irradiation. However, in this case it should be clearly indicated whether it is the instantaneous or average values of GHI or if it is the accumulated values. This study is based on the yearly and monthly values of GHI from a climate station at the Technical University of Denmark (DTU) in Kgs. Lyngby, Denmark, which is described below and shown in Fig. 1.

\subsection{Climate Station}

The climate station, which is described by Andersen (2007) and Lund (1994), Figure 1a, was placed on the roof of building 119 at the Technical University of Denmark (DTU) in Kgs. Lyngby, Denmark. The latitude of the station is $55.8^{\circ} \mathrm{N}$, and the longtitude is $12.5^{\circ} \mathrm{E}$. Data measurements have been carried out since 1989 and are recorded every 2 minutes, either integrated over 2 minutes or instantaneous. From these 2 minutes of data, half hourly and hourly values are created. This study used hourly values. The global irradiance was measured with a Kipp \& Zonen pyranometer CM11, which is shown in Figure 1b. The diffuse irradiance incident on a horizontal surface is measured by a pyranometer with a shadow band blocking any beam radiation, see Figure 1c. The ambient air temperature was measured with a PT1000 sensor.

Data were collected for more than 20 years in 2 minute time-steps by a computer and stored on 3.5 " floppy disks for each single month. After the conversion of the data to the "xls" format, they were evaluated on Excel sheets. The evaluated data in this study from the period 1989 through 2010 are the global irradiance $\left(\mathrm{W} / \mathrm{m}^{2}\right)$, the diffuse irradiance incident on a horizontal surface $\left(\mathrm{W} / \mathrm{m}^{2}\right)$ and the ambient air temperature $\left({ }^{\circ} \mathrm{C}\right)$.

Due to maintenance, human factors and/or measuring device problems during the long-term measurements, there are some missing weather data, e.g., from a few minutes to whole days. These missing measured data were replaced with the average data of the previous and following minutes (days).

\subsection{Solar collectors}

The calculations were carried out with a flat plate solar collector with a reference aperture area of $1 \mathrm{~m}^{2}$ and a tilt of $45^{\circ}$ facing south. The mean fluid temperature in the solar collector was set to $50^{\circ} \mathrm{C}$. The solar collector coefficients are given in Table 1 and are used to describe the solar collector efficiency $\eta$ with the equation:
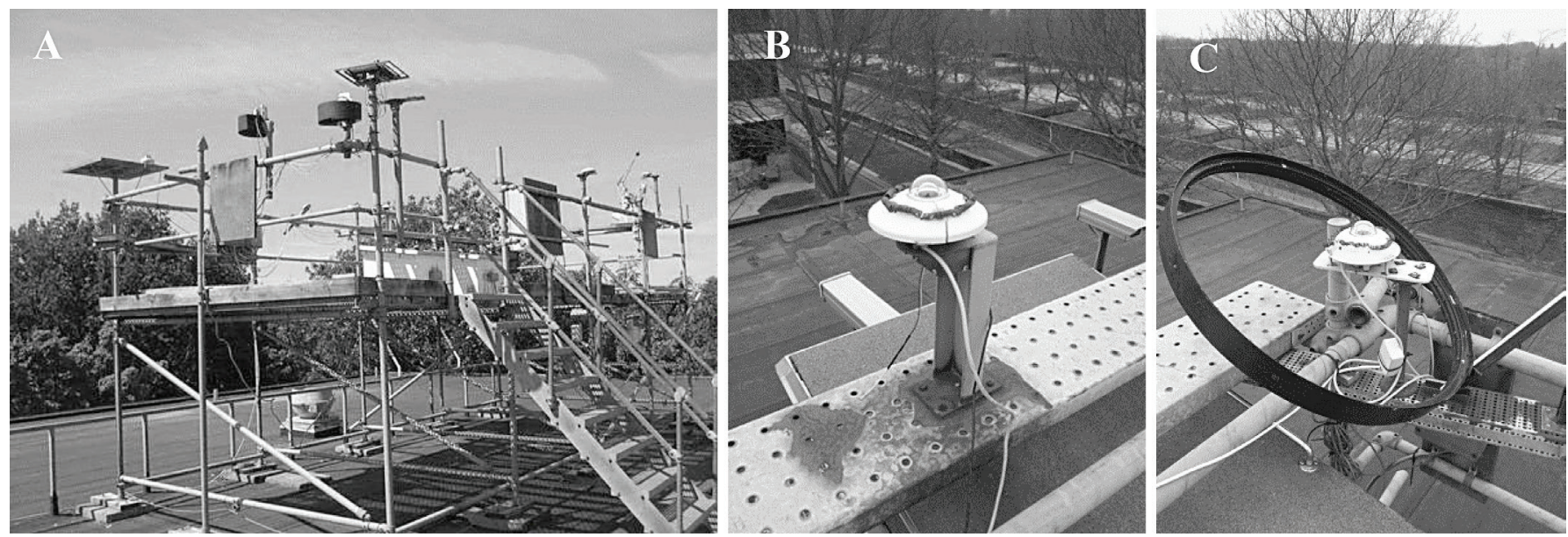

Fig. 1 a) View of the climate station on the roof of building 119 at DTU, b) Pyranometer measuring the global irradiance, c) Pyranometer measuring the diffuse irradiance. 


$$
\eta=k_{\Theta} \eta_{0}-a_{1} \frac{\left(T_{m}-T_{a}\right)}{G}-a_{2} \frac{\left(T_{m}-T_{a}\right)^{2}}{G}
$$

where $\eta_{0}$ is the zero loss efficiency; $a_{1}$ and $a_{2}$ are heat loss coefficients (Table 1); $T_{m}$ is the mean fluid temperature in the solar collector; $T_{a}$ is the ambient air temperature; and $k_{\Theta}$ is the incidence angle modifier (IAM) given by:

$$
k_{\Theta}=1-\tan ^{p}\left(\frac{\Theta}{2}\right)
$$

where $\Theta$ is the incidence angle.

The power of the solar collector $Q\left(\mathrm{~W} / \mathrm{m}^{2}\right)$ was calculated with a model that has a correction term for diffuse radiation (Perers, 2000). The diffuse radiation $G_{d}$ uses a separate IAM that equals the IAM for the beam radiation $G_{b}$ at an incidence angle of $60^{\circ}$ :

$$
Q=\eta_{0} k_{\Theta}(\Theta) G_{b}+\eta_{0} k_{\Theta}\left(60^{\circ}\right) G_{d}-a_{1}\left(T_{m}-T_{a}\right)-a_{2}\left(T_{m}-T_{a}\right)^{2}
$$

The annual collector efficiency $\eta_{a}$ is defined as:

$$
\eta_{\mathrm{a}}=\frac{\text { Yearly the rmal performanc } \mathrm{e}}{\text { Yearly solar radiation }} \times 100
$$

Tab. 1 Parameters of the solar collector.

\begin{tabular}{cccc}
\hline $\begin{array}{c}\text { Zero loss } \\
\text { efficiency, } \eta 0 \\
-\end{array}$ & $\begin{array}{c}\text { Heat loss } \\
\text { coefficient, } \mathrm{a}_{1} \\
\mathrm{~W} / \mathrm{m}^{2} \mathrm{~K}\end{array}$ & $\begin{array}{c}\text { Heat loss } \\
\text { coefficient, } \mathrm{a}_{2} \\
\mathrm{~W} / \mathrm{m}^{2} \mathrm{~K}^{2}\end{array}$ & $\begin{array}{c}\text { IAM } \\
\text { coefficient, } \mathrm{p} \\
-\end{array}$ \\
\hline 0.82 & 3.18 & 0.01 & 3.4 \\
\hline
\end{tabular}

\section{RESULTS}

\subsection{Weather data evaluation}

Twenty years of measuring the data from the climate station at DTU shows a small increase in the ambient air temperature, Figure 2a. The increase is about $0.04 \mathrm{~K}$ per year. Over the last 20 years the average ambient air temperature increased almost $0.7 \mathrm{~K}$.

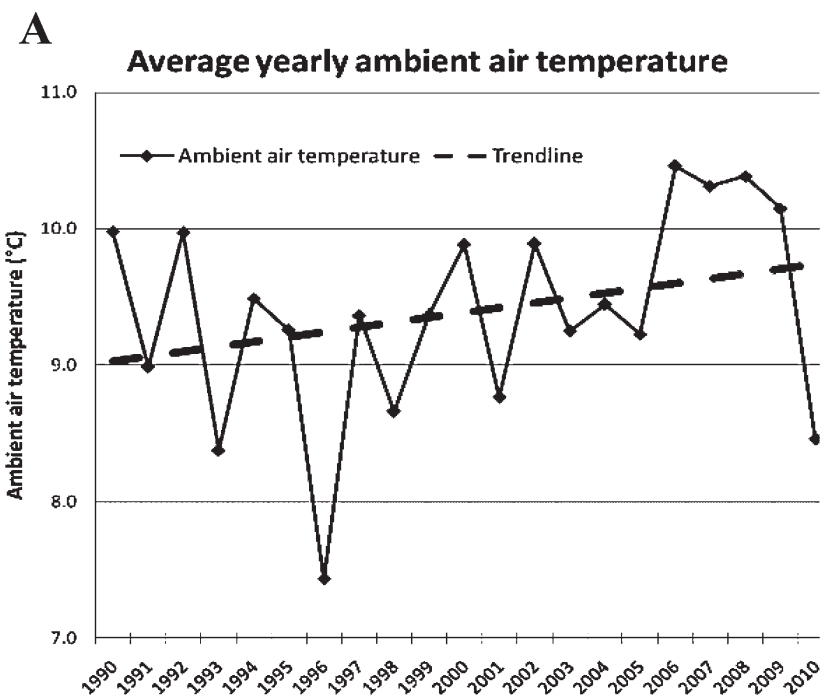

This was mostly due to increased annual global radiation as well as greenhouse gas emissions. The annual average ambient air temperature varied between $7.4{ }^{\circ} \mathrm{C}$ in 1996 and $10.5^{\circ} \mathrm{C}$ in 2006 with an average of $9.4{ }^{\circ} \mathrm{C}$, corresponding to a temperature variation from the warmest year to the coldest year of $3.1 \mathrm{~K}$.

Figure $2 \mathrm{~b}$ shows an increase in global radiation over the last 20 years. An increase of about $3.5 \mathrm{kWh} / \mathrm{m}^{2}$ per year was observed, corresponding to a yearly increase of $0.3 \%$. The yearly increase was $68 \mathrm{kWh} /$ $\mathrm{m}^{2}$, corresponding to $7 \%$ of the global radiation growth over the last 20 years. Solar irradiance is higher when the sun is more active, as indicated by an elevated number of sunspots on its surface according to findings by Rottman et al. (2005). The increase in total solar irradiance is, according to Lean (2010), caused by the three most recent solar activity cycles, which peaked near 1980, 1990 and 2001 and are called cycles 21, 22 and 23 respectively. The high levels of solar irradiance are as well near the peak of cycle $24(\sim 2012-2013)$. The annual global radiation varied between $886 \mathrm{kWh} / \mathrm{m}^{2} /$ year in 1998 and $1088 \mathrm{kWh} / \mathrm{m}^{2} /$ year in 2009 with an average radiation of $1001 \mathrm{kWh} /$ $\mathrm{m}^{2} /$ year, corresponding to a radiation variation from the least sunny year to the sunniest year of about $20 \%$.

This is in good agreement with the findings by Adsten et al. (2001), who have investigated the influence of climate and location on solar collector performances. Three different locations in Sweden were investigated with weather data from 1983 to 1998 . The locations were Lund $\left(55.7^{\circ} \mathrm{N}\right)$, Stockholm $\left(59.3^{\circ} \mathrm{N}\right)$ and Luleå $\left(65.6^{\circ} \mathrm{N}\right)$. The variations in total solar radiation on a south-facing $45^{\circ}$-tilted surface from the least sunny year to the sunniest year were $19 \%, 23 \%$ and $26 \%$, respectively.

The results of the diffuse radiation measurements are shown in Figure 3a. According to the trendline, there has been a growth in diffuse radiation over the years. The increase in diffuse radiation is $1.9 \mathrm{kWh} / \mathrm{m}^{2}$ per year, corresponding to a yearly increase of $0.4 \%$ and a 20 -year increase of $37 \mathrm{kWh} / \mathrm{m}^{2}$, corresponding to $7 \%$. The annual diffuse radiation varied between $473 \mathrm{kWh} / \mathrm{m}^{2} /$ year in 1995 and $574 \mathrm{kWh} / \mathrm{m}^{2} /$ year in 1992, with an average radiation of $526 \mathrm{kWh} / \mathrm{m}^{2} /$ year, corresponding to a radiation variation from the least cloudy year to the cloudiest year of $19 \%$.

Figure $3 \mathrm{~b}$ shows a comparison of the measured direct and diffuse radiation incident on a horizontal surface. Generally, it can be observed that the sum of the direct and diffuse radiation equals the global radiation, which is two times larger than the diffuse radiation incident on a horizontal surface.

B

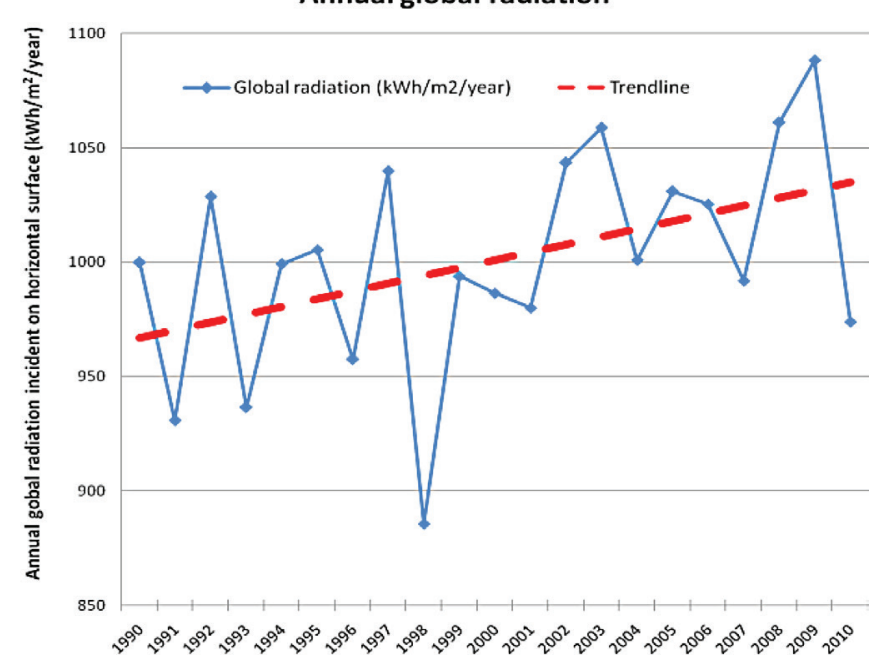

Fig. 2 Twenty-year annual average of a) Ambient air temperature, b) Solar global radiation incident on a horizontal surface. 

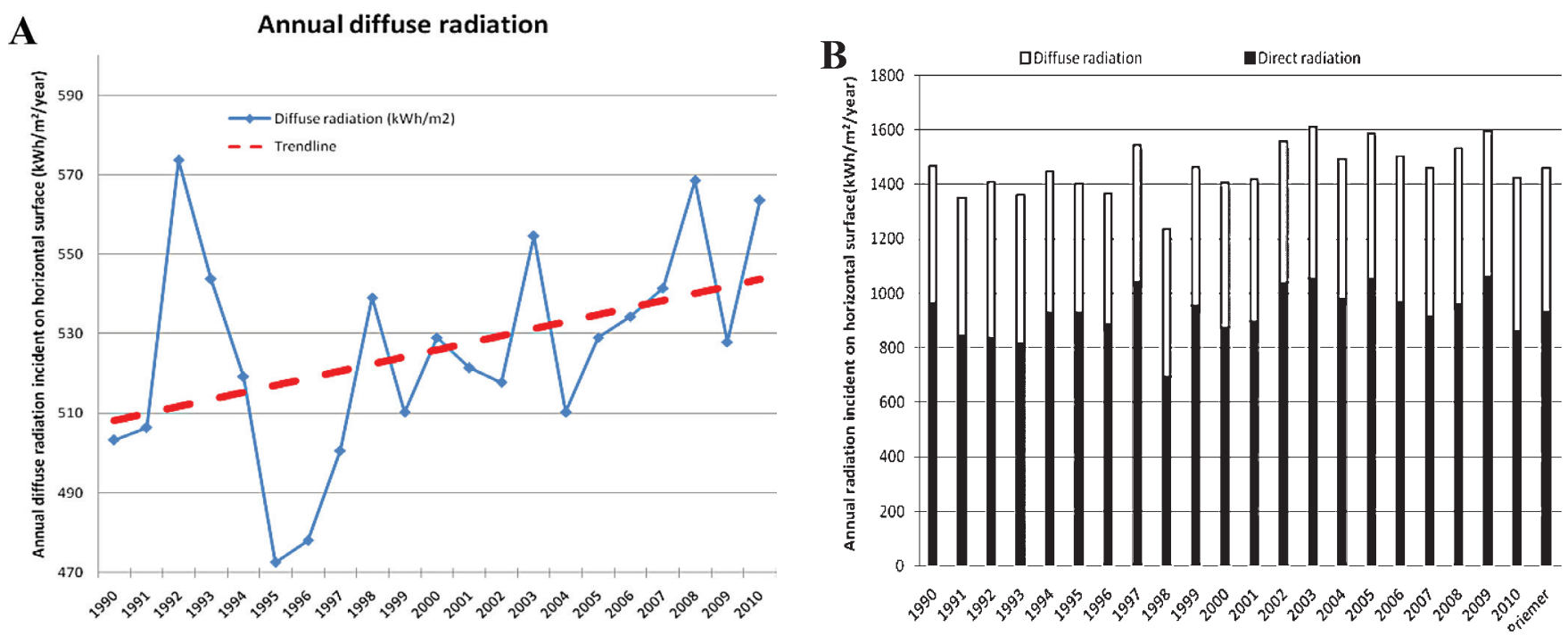

Fig. 3 Twenty-year annual average of a) Solar diffuse radiation incident on a horizontal surface, b) The direct and diffuse radiation incident on a horizontal surface.

A

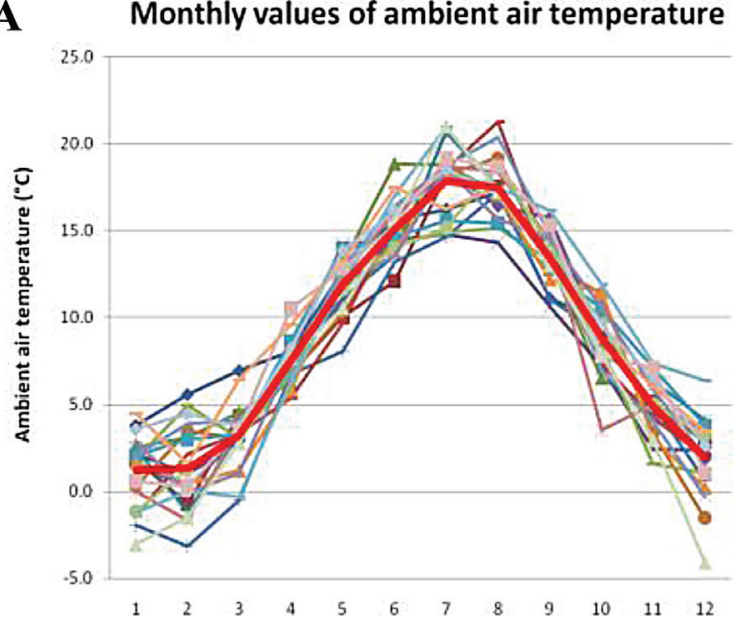

C

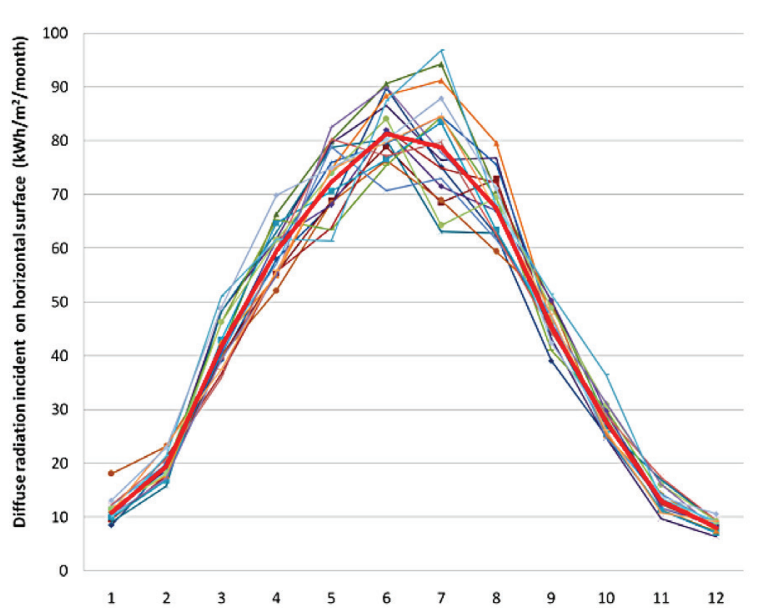

Fig. 4 Twenty-year monthly average of a) ambient air temperature, b) global radiation incident on a horizontal surface, c) diffuse radiation incident on a horizontal surface.
B
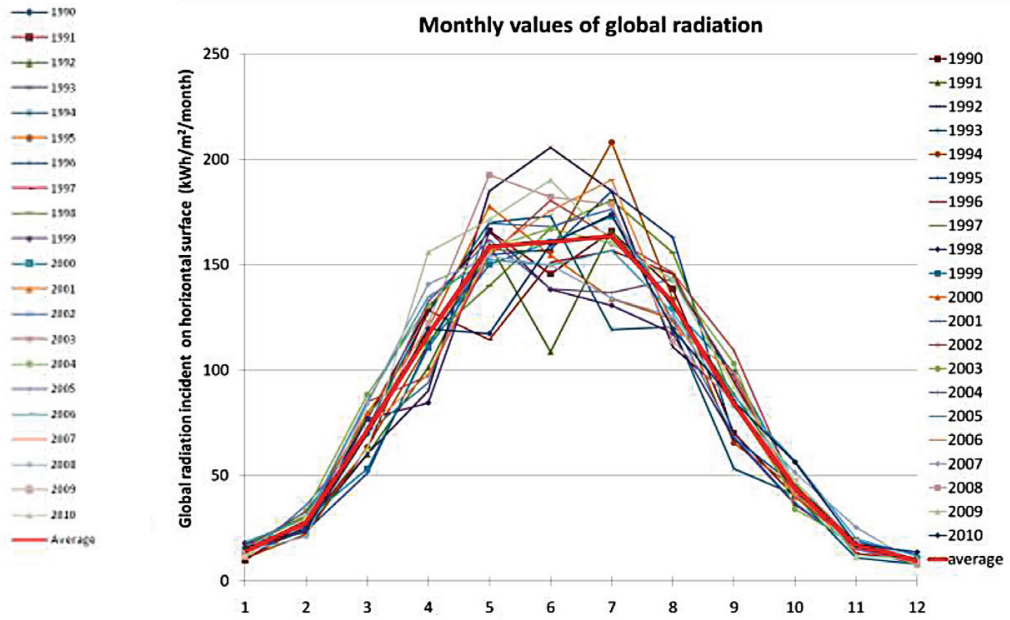

The variations in the monthly average ambient air temperature were higher in the winter period than in the summer (see Figure 4a), while the variations of the monthly global radiations were higher in the summer period than in the winter (see Figure 4b). A similar behavior as in global radiation measurements was observed in the average monthly diffuse radiation on the horizontal measurements (see Figure 4c). The variations in diffuse radiation were higher in the summer period and almost identical in the winter period. The red curves in Figure 4 show the monthly averages of the 20 years examined.

Figure 5 shows the seasonal yearly average of the ambient air temperature, global and diffuse radiation incident on a horizontal surface. The summer period was from May to September; the autumn months are October and November; the winter is from December to February; and the spring months were March and April. The increase in ambient air temperature was mostly due to the summer months, and a decrease in the ambient air temperature in the past years was even registered in the winter months, i.e., that the summer period became warmer and the winter period became colder over the past 20 years (see Figure 5a). The highest increase in global radiation was recorded in the spring months (see Figure 5b), while the diffuse ra- 


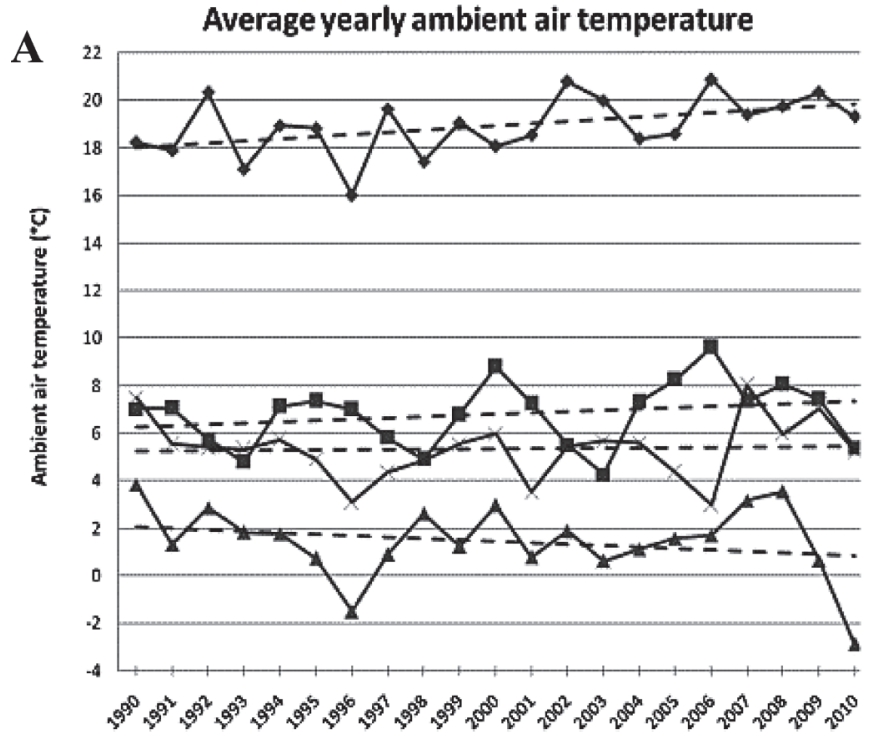

C

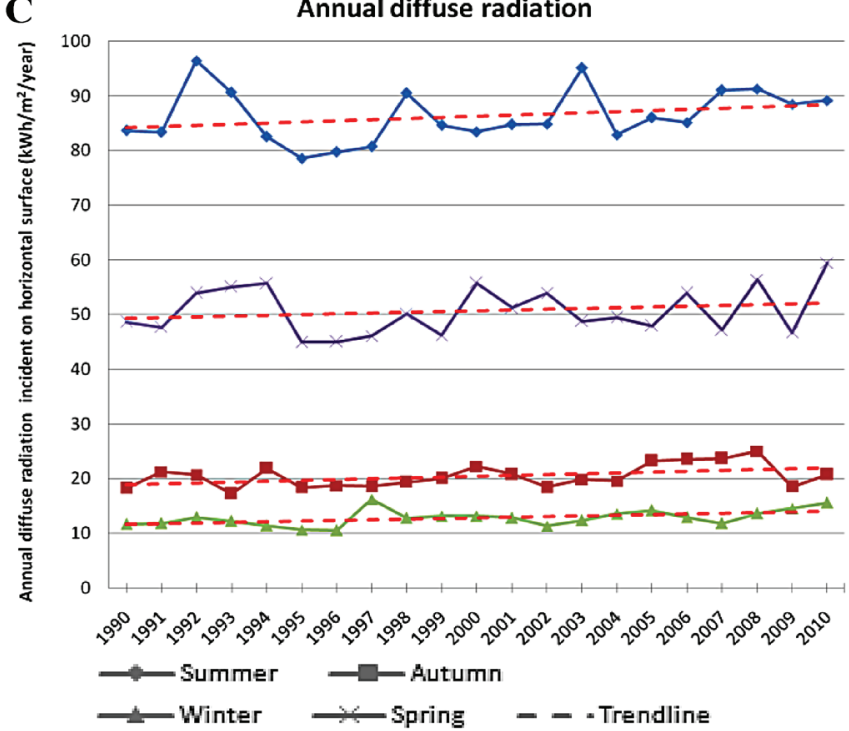

Fig. 5 Twenty-year seasonal yearly average of a) ambient air temperature, b) global radiation incident on a horizontal surface, c) diffuse radiation incident on a horizontal surface.

diation increased mostly in the summer period (see Figure $5 \mathrm{c}$ ). The autumn and winter months were without any significant growth in global and diffuse radiation.

\subsection{Thermal performance of a solar collector}

The thermal performance of a solar collector with a reference collector area of $1 \mathrm{~m}^{2}$ was calculated for 1998, the year with the lowest annual global radiation, see Figure 6a, and for 2009, the year with the highest global radiation, see Figure $6 \mathrm{~b}$. The difference between the total solar radiation and diffuse radiation is the beam (direct) radiation. Figures $6 \mathrm{a}$ and $6 \mathrm{~b}$ show that the thermal performance was mainly dependent on the beam radiation. Table 2 shows the yearly thermal performance, the total solar radiation on a $45^{\circ}$ tilted surface facing south, and the utilization of the solar radiation of a reference
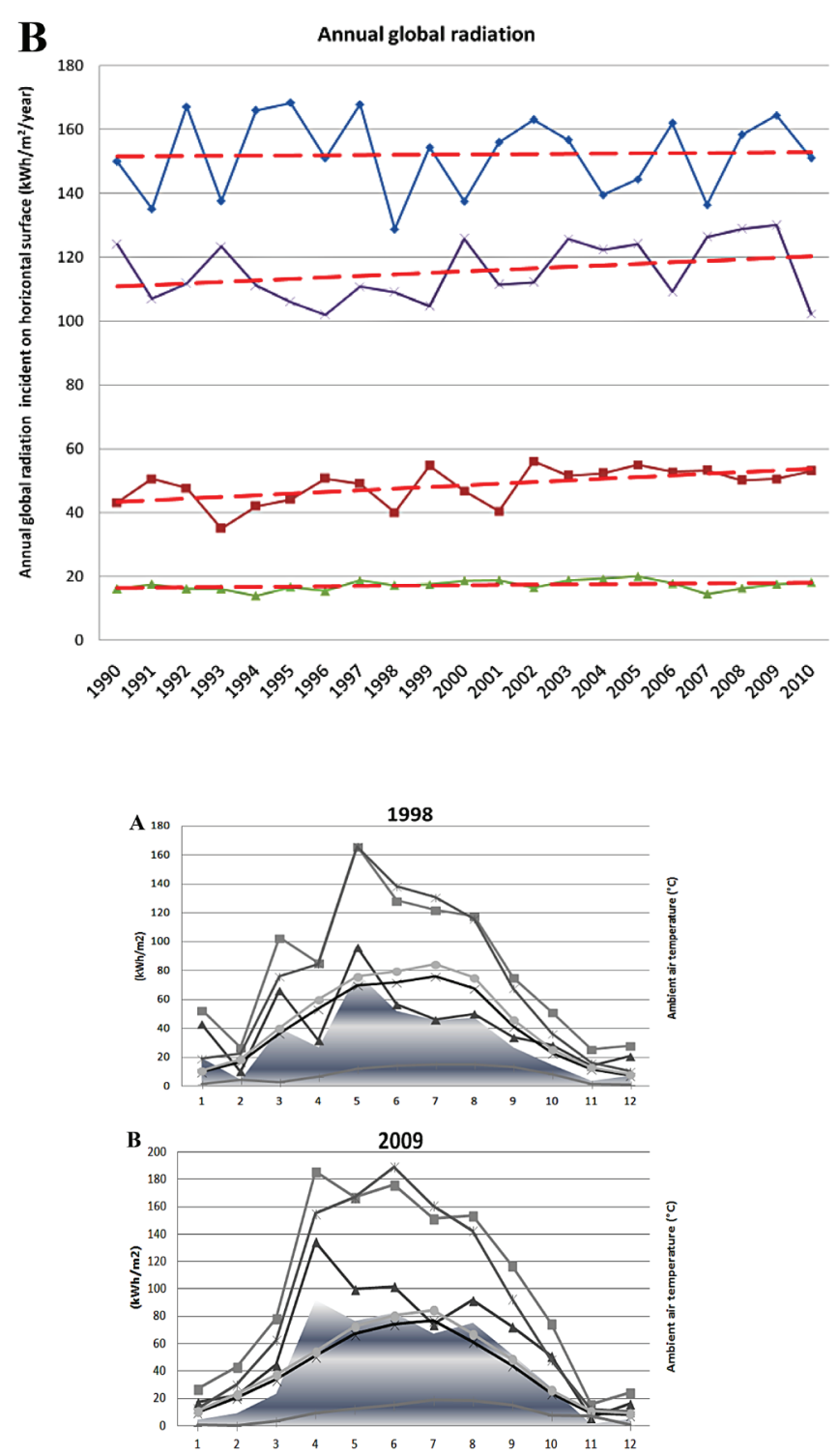

$=$ Thermal performance-s $\left(\mathrm{kWh} / \mathrm{month}^{*} \mathrm{~m} 2\right)$ -Global radiation incident on horizontal surface (kWh/month $\left.{ }^{*} \mathrm{~m} 2\right)$ - - -Diffuse radiation incident on horizontal surface $\left(\mathrm{kWh} / \mathrm{month}^{*} \mathrm{~m} 2\right)$

Fig. 6 Monthly plot of the thermal performance per $m^{2}$ solar collector and total, beam and diffuse radiation on the collector as well as the global and diffuse radiation incident on a horizontal surface and ambient air temperature for the years a) 1998, b) 2009.

solar collector placed in Lyngby for the years with a minimum (1998) and maximum (2009) amount of global radiation incident on a horizontal surface. The total solar radiation is calculated by the sum of the beam and diffuse radiation incident on a tilted surface. A constant solar collector fluid temperature of $50{ }^{\circ} \mathrm{C}$ in the solar collector was assumed during all hours of the year.

Tab. 2 Yearly results for the reference solar collector area of $1 \mathrm{~m}^{2}$.

\begin{tabular}{cccc}
\hline Year & $\begin{array}{c}\text { Yearly thermal } \\
\text { performance } \\
\mathrm{kWh} /\left(\text { year.m }^{2}\right)\end{array}$ & $\begin{array}{c}\text { Total solar } \\
\text { radiation } \\
\mathrm{kWh} /\left(\text { year. }^{2}\right)\end{array}$ & $\begin{array}{c}\text { Annual collector } \\
\text { efficiency } \\
\%\end{array}$ \\
\hline 1998 & 369 & 983 & 37.5 \\
2009 & 557 & 1215 & 45.8 \\
\hline
\end{tabular}




\section{DISCUSSION}

The previous investigations of Andersen (2004) show that there is no reasonable linear relationship between the yearly global radiation and the yearly total solar radiation on a south-facing $45^{\circ}$-tilted surface. It was also investigated that the annual efficiency of solar radiation for all types of solar collectors is increasing for the annual solar radiation on a collector.

Adsten et al. (2001) investigated the influence of the climate and location on solar collector performances. Three different locations in Sweden were investigated with weather data from 1983 to 1998 . The locations were Lund $\left(55.7^{\circ} \mathrm{N}\right)$, Stockholm $\left(59.3^{\circ} \mathrm{N}\right)$ and Luleå (65.6 $\left.{ }^{\circ} \mathrm{N}\right)$. The variations in total solar radiation on a south-facing $45^{\circ}$-tilted surface from the least sunny year to the sunniest year are $19 \%, 23$ $\%$ and $26 \%$, respectively. The investigation included a flat plate collector and an evacuated tubular collector. The authors found that the solar radiation variations are larger the further away from the equator the location is and that the collector output is strongly influenced by the solar irradiance and less influenced by the ambient air temperature during its operation, which corresponds with the results in this study according to Figure 6. Further, they found that the relation between the global radiation and the solar collector's output could be fitted to a linear equation.

According to the Intergovernmental Panel on Climate Change (2007), an overall warming trend is apparent in the climate of the last two decades of the 20th century.Brohan et al. (2006) investigated that from 1980 to 2000 , global surface temperatures increased at an average rate of $0.16^{\circ} \mathrm{C}$ per decade, with 1998 being the warmest year on record, i.e., $0.6^{\circ} \mathrm{C}$ above the global average for $1951-1980$. But a relative lack of warming has characterized the first decade of the $21 \mathrm{st}$ century, even though greenhouse gas concentrations have continued to increase. Confounding the expectations of a monotonically warming globe, the average warming rate from 2000 to 2008 subsided by almost an order of magnitude, and temperatures in 2008 were cooler than in 2002. These varying 'trends' in global temperatures arise in part from the influences of solar irradiance and other natural processes (volcanic activity), which must be comprehensively assessed in order to properly ascertain the Earth's response to any underlying anthropogenic influence.

Scafetta (2008) claims that the sun has caused as much as $70 \%$ of recent global warming (based in part on the attribution of radiometric trends to actual solar irradiance changes), which presents fundamental puzzles. It requires that the sun's brightness has increased more in the past century than at any time in the past millennium, including over the past 30 years, which is contrary to direct space-based observations. And it requires, as well, that Earth's climate be insensitive to well-measured increases in greenhouse gases at the same time that it is excessively sensitive to poorly-known changes in solar brightness. Both scenarios are far less plausible than the simple attribution of most $(90 \%)$ of industrial global warming to anthropogenic effects rather than to the Sun.

One approach for forecasting climate in future decades is to estimate the effect from expected changes in the individual natural and anthropogenic influences. This approach assumes that climate will continue to respond linearly to these influences, as parameterized using past observations by Rind (2009). The future climate scenario suggests an average warming rate of $0.17{ }^{\circ} \mathrm{C}$ per decade in response to projected solar irradiance cycles similar to cycle 23 and an anthropogenic forcing of $0.37 \mathrm{Wm}^{-2}$ per decade (the trend in the recent past). The warming trend is comparable to the $0.2{ }^{\circ} \mathrm{C}$ per decade warming forecast by Intergovernmental Panel on Climate Change (2007), but contrary to recent projections of findings by Keenlyside (2008), who forecasts an absence of warming in the next decade based on the weakening of the Atlantic Ocean's meridianal overturning circulation.

Global warming will probably not proceed at a constant rate in the immediate future. As anthropogenic influences continue and solar irradiance increases from the onset to the maximum of cycle 24, global surface temperatures are projected to increase $0.14{ }^{\circ} \mathrm{C}$ in the five years from 2009 to 2014 (at an average rate of $0.3^{\circ} \mathrm{C}$ per decade). Global annual temperatures in 2014 will be $0.7{ }^{\circ} \mathrm{C}$ warmer than the 1951-1980 base period, but the estimated annual temperature increase of $0.2{ }^{\circ} \mathrm{C}$ from 2004 to 2014 is smaller than the $0.3^{\circ} \mathrm{C}$ warming that Smith (2007) predicted over the same interval. From 2014 to 2019, global annual surface temperatures are expected to increase only minimally $\left(0.03^{\circ} \mathrm{C}\right)$, as declining solar irradiance cancels much of the anthropogenic warming, analogous to the recent period from 2002 to 2008, when the decreasing solar irradiance during the descending phase of solar cycle 23 countered much of the anthropogenic warming. Although the El Nino Southern Oscillation (ENSO) fluctuations and volcanic eruptions are not predictable on decadal time scales, the global surface temperature of a Pinatubo-like eruption with a peak impact in 2014 (near solar cycle 24 maximum) and a super ENSO with maximum impact in 2019, would mimic a similar sequence that occurred from 1992 to 1997.

\section{CONCLUSIONS}

The influence of weather data on the thermal performance of solar systems with solar collectors was investigated theoretically. The investigation was based on calculations with weather data from the Danish Climate Station placed at the Danish University of Technology for the years from 1990 to 2010. Although the results in the study are based on weather data from Denmark, the results are not specific to the Danish conditions, but show how the thermal performances of solar systems are generally influenced by weather variations.

The annual thermal performance of solar systems with solar collectors increases with increases in annual solar radiation.

From the weather data measurements it is obvious that there was a trend of increasing global radiation as well as diffuse radiation and ambient air temperatures over the past 20 years. The ambient air temperature in the winter period is decreasing. Generally, the ambient air temperature does not have a high influence on the thermal performance of solar collectors compared to the influence of the total solar radiation.

\section{Acknowledgement}

The project is supported by Scientific Grant Agency of the Ministry of Education of Slovak Republic and Slovak Academy of Sciences VÚ VEGA 1/1052/11. 


\section{REFERENCES}

Adsten, M. - Perers, B. - Wäckelgård, E. (2001) The influence of climate and location on collectorperformance. Renewable Energy 25 , pp. 499-509.

Andersen, E. - Shah, L. J. - Furbo, S. (2004) Thermal performance of Danish solar combi systems in practice and in theory. Journal of Solar Energy Engineering, pp. 744-749.

Andersen, E. (2007) Solar Combi Systems. PhD Thesis, Department of Civil Engineering, Technical University of Denmark, ISBN 978-89-7877-228-2

Brohan, P. - Kennedy, J. J. - Harris, I. - Tett, S. F. B. - Jones, P. D. (2006) Uncertainty estimates in regional and global observed temperature changes: a new dataset from 1850. J Geophys Res 2006, 111. DOI:10.1029/2005JD006548

Intergovernmental Panel on Climate Change. (2007) Fourth Assessment Report, Working Group I.

Keenlyside, N. S. - Latif, M. - Jungclaus, J. - Kornblueh, L. - Roeckner, E. (2008) Advancing decadal-scale climate prediction in the North Atlantic sector. Nature 2008, 453, 84-88, DOI:10.1038/nature06921

Lean, J. L. (2010) Cycles and trends in solar irradiance and climate. Wiley Interdisciplinary Reviews: Climate Change 1, pp. 111-122.

Lund, H. (1994) Solar Measurement Station. Thermal Insulation Laboratory. Technical University of Denmark. Report 94-18.
Perers, B. (2000) A Solar Collector Model and Emulator for IEA Task 26, Description for Solar Thermal System Testing. Based on the CEN 12975 and the TRNSYS Type 132 Collector Model. Battenfall Utveckling AB.

Rind, D. H. - Lean, J. L. (2009) How will Earth's surface temperature change in future decades? Geophys Res Lett 2009, 36, L15708. DOI:10.1029/2009GL038932

Rottman, G. - Lean, J. - Harder, J. - Kopp, G. (2005) Solar Radiation and Climate Experiment contributions to new understanding of global change and solar variability. Solar Phys, 230, 1-2, 27-53. DOI:10.1007/s11207-005-1527-2

Scafetta, N. - West, B. J. (2008) Is climate sensitive to solar variability? Phys Today 2008, 61, 3, pp. 50-51.

Smith, D. M. - Cusack, S. - Colman, A. W. - Folland, C. K. - Harris, G. R. - et al. (2007) Improved surface temperature prediction for the coming decade from a global climate model. Science 2007, 317, pp. 796-799.

Weiss, W. (2003) Solar Heating Systems for Houses - a Design Handbook for Solar Combisystems. IEA Task 26: "Solar Combisystems", Germany, ISBN 1-902916-46-8 